\title{
ERRATUM
}

\section{Rise of Competitive Authoritarianism in Bangladesh-ERRATUM}

\author{
Shafi Md. Mostofa ${ }^{1,2}$
}

${ }^{1}$ University of New England, Australia

${ }^{2}$ University of Dhaka, Bangladesh

\section{B. Subedi ${ }^{1}$}

${ }^{1}$ University of New England, Australia

https://doi.org/10.1017/S1755048320000401. Published by Cambridge University Press, 13 July 2020

There were editorial errors in Mostafa's name and the affiliations as well as the abstract in the original online version of this article (published 13 July 2020). In addition, Mostofa's ORCID number was omitted. These errors have been corrected online and will be corrected in print as well.

We regret the errors.

\section{REFERENCE}

Mostofa, S. M. and D. B. Subedi. published online 13 July 2020. "Rise of Competitive Authoritarianism in Bangladesh." Politics and Religion. https://doi.org/10.1017/ S1755048320000401. 